\title{
Boreal mixedwood stand dynamics: Ecological processes underlying multiple pathways ${ }^{1}$
}

\author{
by Yves Bergeron ${ }^{1,6,7}$, Han Y.H. Chen², Norman C. Kenkel ${ }^{3}$, Albanie L. Leduc ${ }^{4}$ and S. Ellen Macdonald ${ }^{5}$
}

\begin{abstract}
The southern portions of the boreal region across Canada are dominated by boreal mixedwoods forests, which are characterized by varying canopy dominance of boreal broadleaf and conifer trees. This forest region encompasses a large east-to-west gradient of climate and disturbance regimes. Although the same major boreal tree species occur in all parts of the boreal mixedwood region, they vary greatly in relative abundance. This is a reflection of the interactions among the different abiotic and biotic components. As a result, there is considerable variation in post-disturbance stand development, producing a wide variety of mixedwood forest conditions existing as a mosaic in time and space. Post-disturbance dominance by broadleaf species followed by a transition to conifers is the "classic" pathway in all regions. However, there is wide variation in the transition rate and the species sequence across the gradient depending on factors such as moisture, abundance of each species, fire cycle, climate and secondary disturbances (mainly insect outbreaks). Future changes in climate and disturbance regime could influence the nature of stand dynamics of boreal mixedwoods and the prominence of different pathways among regions. Focussing on the commonality of processes in mixedwood stand development across the boreal is a promising way to address the management of this important forest ecosystem.
\end{abstract}

Keywords: Canadian boreal mixedwood forest, stand dynamics, fire disturbance, insect disturbance, forest management emulating natural stand dynamics

\section{RÉSUMÉ}

Le sud de la région boréale canadienne est dominé par la forêt boréale mixte, caractérisée par une canopée à dominance feuillue et coniférienne en différentes proportions. Cette région forestière traverse dest en ouest, un large gradient climatique et différents régimes de perturbation. Les espèces principales de la forêt boréale mixte sont les mêmes à travers le Canada, mais leur importance relative varie. Cela reflète les interactions entre les différentes composantes biotiques et abiotiques de lécosystème. Le développement d'un peuplement après perturbation peut prendre différentes tangentes ce qui fait qu'il existe plusieurs types de forêts boréales mixtes qui se présentent sous forme de mosaïques spatiales et temporelles. Une dominance feuillue après perturbation, suivie d'une transition vers les conifères, constitue la séquence temporelle " classique » de la dynamique forestière dans toutes les régions. Toutefois, les taux de transition et les séquences despèces varient grandement à travers le gradient. Cette variabilité dépend principalement du régime d'humidité, de labondance de chaque espèce, du cycle de feu, du climat et des perturbations secondaires (surtout les épidémies d'insectes). Les changements climatiques futurs et le régime de perturbations pourraient influencer la nature de la dynamique des peuplements de la forêt boréale mixte et limportance relative des différents patrons temporels à travers les régions. Bien comprendre les processus communs au développement des peuplements de la forêt boréale mixte est une façon prometteuse d'entreprendre laménagement forestier de cet important écosystème.

Mots clés : forêt boréale mixte canadienne, dynamique des peuplements, perturbation par le feu, épidémies d'insectes, aménagement forestier reproduisant la dynamique naturelle du peuplement

\section{Introduction}

Forest composition and structure, and how these change over time, are a result of complex interactions involving the regional species pool and the ecological properties of these species, environmental conditions, and disturbances; this complexity can result in a variety of possible pathways of stand dynamics
(Cattelino et al. 1979). Maintenance of diversity in forest composition can play a role in conservation of biodiversity and habitat (Hobson and Bayne 2000, Cavard et al. 2011), and in forest productivity, resistance and resilience (De Grandpré and Bergeron 1997, Brassard et al. 2011, Bartels and Chen 2012, Zhang et al. 2012). However, this diversity represents a

\footnotetext{
${ }^{1}$ This paper should have appeared in The Forestry Chronicle, Vol. 90, No.1 - "Boreal Mixedwood 2012 Conference”.

${ }^{2}$ Professor, NSERC-UQAT-UQAM Industrial Chair in Sustainable Forest Management, Université du Québec en Abitibi-Témiscamingue, RouynNoranda, QC.E-mail: yves.bergeron@uqat.ca

${ }^{3}$ Professor, Faculty of Natural Resources Management, Lakehead University, Thunder Bay, ON. E-mail: hchen1@lakeheadu.ca

${ }^{4}$ Professor, Department of Biological Sciences, University of Manitoba, Winnipeg, MB. E-mail: Norman.Kenkel@ad.umanitoba.ca

${ }^{5}$ M.Sc. student, Centre d’Étude sur la forêt, Université du Québec à Montréal, Montréal, QC. E-mail: albanieleduc@hotmail.com

${ }^{6}$ Professor, Department of Renewable Resources, University of Alberta, Edmonton, AB. E-mail: emacdona@ualberta.ca

*Author to whom correspondence should be sent.

${ }^{\dagger}$ Authors are listed in alphabetical order.
} 


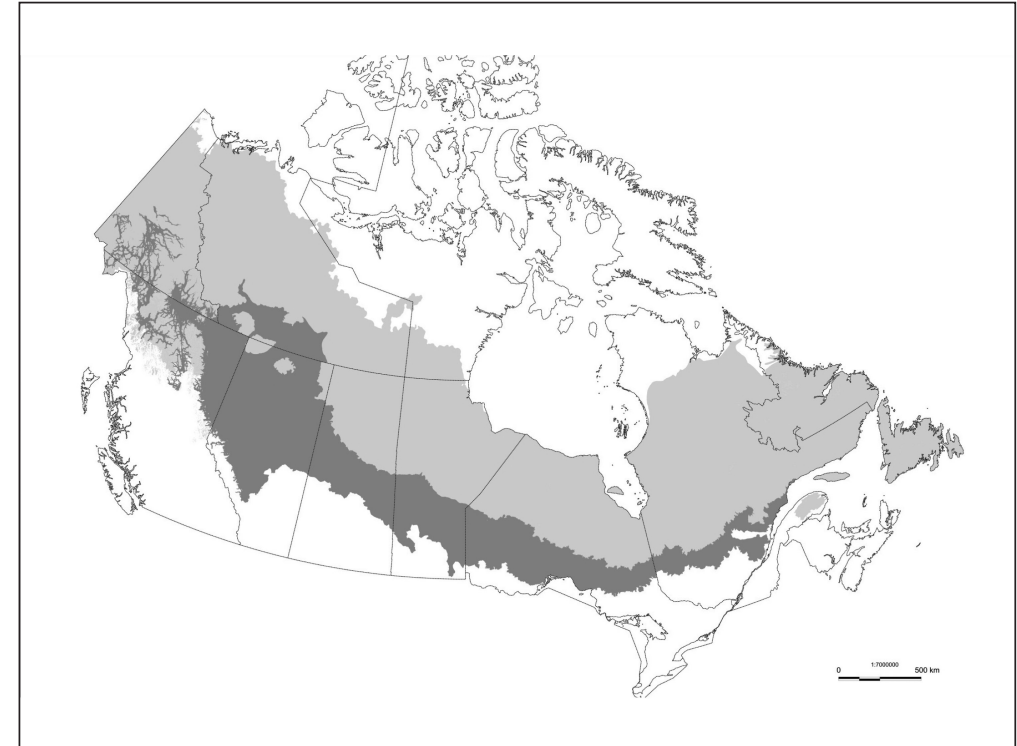

Fig. 1. Map of the extent of boreal forest in Canada (light and dark grey areas; Brandt 2009). The boreal mixedwood (dark grey area) corresponds to the thermoboreal bioclimatic subdivision of the Canadian boreal biome, version 1 (Baldwin et al. 2012), Circumboreal Vegetation Map (CBVM) (Talbot and Meades 2011).

challenge for management (Lieffers et al. 1996a, Lieffers et al. 2008). The complexity of managing for several species coexisting in the canopy has led to a tendency in recent decades to employ management systems which could lead to an "unmixing" of mixed species forests (Man and Lieffers 1999, Jackson et al. 2000, Lieffers et al. 2008). A new paradigm of forest management invokes emulating natural disturbances and stand dynamics of natural systems as an approach to ensure future forest sustainability (Burton et al. 2006). Such an approach necessarily depends upon a solid understanding of forest dynamics.

Table 1. Summary of key differences between the eastern and western portions of the boreal mixedwood region in Canada (Hare and Thomas 1979, Larsen 1980, Fulton 1989, Lenihan 1993).

\begin{tabular}{|c|c|c|}
\hline Characteristic & $\begin{array}{c}\text { West (Yukon, Northwest Territory, } \\
\text { British Columbia, Alberta, } \\
\text { Saskatchewan, Manitoba) }\end{array}$ & East (Ontario and Quebec) \\
\hline Temperature & \multicolumn{2}{|c|}{ Similar across Canada in the boreal mixedwood zone } \\
\hline $\begin{array}{l}\text { Annual } \\
\text { precipitation }\end{array}$ & $400-600 \mathrm{~mm}$ (dry) & $600-1200 \mathrm{~mm}$ (moist) \\
\hline $\begin{array}{l}\text { Main surficial } \\
\text { deposit }\end{array}$ & Clay (with some till) & Till (except for the clay belt) \\
\hline Main bedrock & Sedimentary (Calcareous-basic) & $\begin{array}{l}\text { Intrusive-metamorphic } \\
\quad \text { (Granite-acidic) }\end{array}$ \\
\hline $\begin{array}{l}\text { Major tree } \\
\text { species }\end{array}$ & $\begin{array}{l}\text { Trembling aspen } \\
\text { Balsam poplar } \\
\text { Paper birch } \\
\text { White spruce }\end{array}$ & $\begin{array}{c}\text { Paper birch } \\
\text { Trembling aspen } \\
\text { Balsam fir } \\
\text { White spruce } \\
\text { White cedar }\end{array}$ \\
\hline Fire & $\begin{array}{l}\text { Short cycle } \\
\text { Very Large }\end{array}$ & $\begin{array}{l}\text { Long cycle } \\
\text { Large }\end{array}$ \\
\hline $\begin{array}{l}\text { Secondary } \\
\text { disturbances }\end{array}$ & $\begin{array}{c}\text { Drought } \\
\text { Forest tent caterpillar }\end{array}$ & Spruce budworm \\
\hline
\end{tabular}

In Canada, the boreal mixedwood region forms a wide belt encompassing a large proportion of the boreal forest distributed over six provinces and two territories (Fig. 1). This region is characterized by a complex mosaic of forest types that vary both structurally and in the relative proportion of broadleaf and conifer tree species. This highly productive and diverse ecosystem is influenced by a strong east-to-west gradient in climate, edaphic conditions, and disturbance regimes (Table 1). Surficial deposits west of the Rocky Mountains are mainly characterized by colluvial till, the western portion of the zone, located in the central plains, is characterized by clay and till deposits; the eastern portion of the mixedwood region is characterized by tills except in the clay belt, which overlaps the border between Ontario and Quebec (Fulton 1989). There is a strong precipitation gradient, from drier in the west to moister conditions in the east attributable to the Atlantic Ocean influence (Hare and Thomas 1979). Together, climate and soils/surficial deposits influence vegetation as much as disturbances and thus play a major role in stand dynamics (Larsen 1980).

The major species and their relative abundances also vary from west to east (Lenihan 1993), resulting in variation in the species mixture and in the ratio of broadleaf to conifer species. Generally, conifers are more abundant in the east. Trembling aspen (Populus tremuloides Michx.) is the dominant broadleaf on clay and tills in the west, whereas paper birch (Betula papyrifera Marsh.) is the main broadleaf on eastern tills. In the western portion of the boreal mixedwood region, balsam fir (Abies balsamea [L.] Mill.) has low abundance and eastern white cedar (Thuja occidentalis L.) is completely absent; these two conifers play key roles in the east (Bergeron 2000).

Various natural disturbances, which are influenced themselves by climate and landscape features, influence species distributions and relative abundances. In the west wildfires are large and frequent, whereas in the east the natural fire regime is characterized by smaller and less frequent fires (Bergeron and Fenton 2012; Table 1). These differences in fire size and frequency strongly influence forest vegetation composition, structure and dynamics (Bergeron and Dansereau 1993, Kneeshaw and Gauthier 2003, McIntire et al. 2005, Johnstone and Chapin 2006b, Bouchard and Pothier 2008, Bouchard et al. 2008, Brassard et al. 2008, Johnstone et al. 2010). The other important natural disturbance, insect outbreaks, depends on the prior stand type and landscape forest composition (Campbell et al. 2008, Colford-Gilks et al. 2012, Nixon and Roland 2012). Spruce budworm is more prevalent in the east because of the prominence of balsam fir, its preferred host (Blais 1983). Forest tent caterpillar is present throughout the boreal mixedwoods, but is a more influential 
disturbance agent in the western boreal, because trembling aspen is one of the most common tree species (Hogg and Schwarz 1999, Cooke and Roland 2007, Sutton and Tardif 2007). Aspen in western Canada is also impacted by severe drought conditions that reduce growth and cause dieback (Hogg et al. 2002, Brandt et al. 2003, Frey et al. 2004, Hogg et al. 2008).

Our objective herein is to reconcile our understanding of the diversity of patterns and processes in stand dynamics of boreal mixedwoods across Canada as a basis for informing management approaches for this region. To this end we: 1) examine the different factors driving mixedwood stand dynamics and how these vary across Canada, 2) summarize the variability in pattern and process of boreal mixedwood stand dynamics observed across Canada, and 3) briefly discuss applications of this knowledge to forest management.

\section{Drivers of Stand Dynamics and Forest Composition}

"Stand dynamics" are defined as changes in stand structure and species composition over time following a stand-replacing disturbance (Oliver and Larson 1996, Chen and Popadiouk 2002). Variability in stand structure and composition reflects differences in dominant species and environmental conditions, and associated disturbance regimes (e.g., McIntire et al. 2005, Shorohova et al. 2009). Typically, early post-fire mixedwood stands are dominated by shade-intolerant species (mostly broadleaf species, but could include pines) that are gradually replaced over time by shade-tolerant species (mainly conifers). This idealized broadleaf to conifer transition is quite variable, however, depending on both the nature of the stand-initiating disturbance and the compositional history of the disturbed forest stand and its surroundings (Bergeron and Dubuc 1989, Bergeron 2000, Chen and Popadiouk 2002, Awada et al. 2004, Park et al. 2005, Taylor and Chen 2011).

Time alone is an insufficient predictor of species dynamics in the boreal forest (Park et al. 2005, Taylor and Chen 2011).

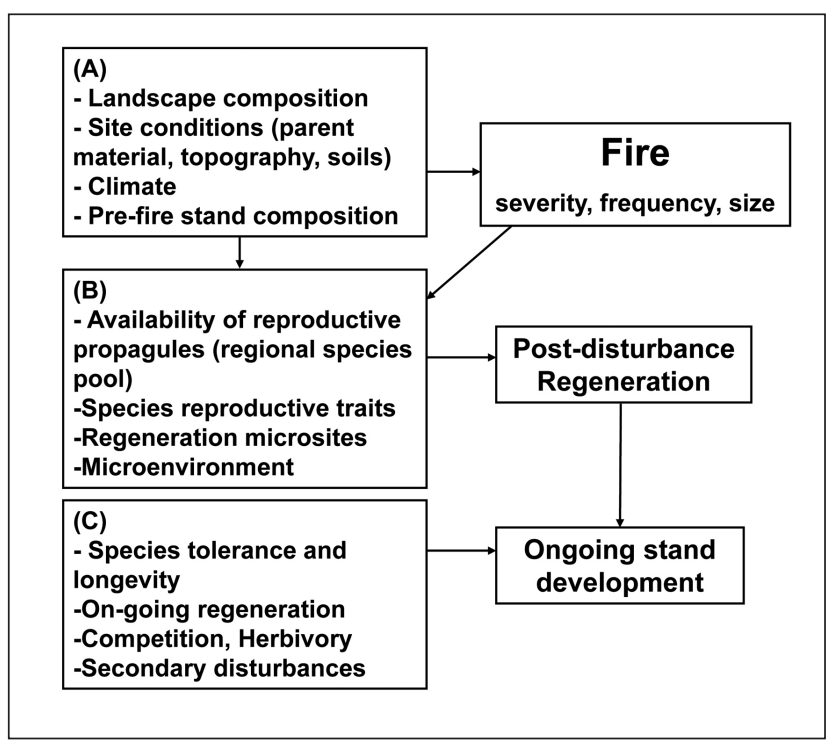

Fig. 2. The influence of abiotic and biotic factors and wildfire on post-fire regeneration and ongoing stand dynamics in boreal mixedwoods. Site-level factors (box "A") influence fire; both these determine those factors in box "B", which in turn drive postdisturbance regeneration. That regeneration, plus the influence of factors in box " $\mathrm{C}$ " drive ongoing stand development.
Factors such as characteristics of the fire (e.g., severity), pre-fire stand and landscape floristic composition, site conditions and climate, regeneration processes, and stochasticity influence early post-fire forest composition (Fig. 2). Subsequent development of structure and composition is a function of ongoing regeneration processes, species life history, biotic interactions, abiotic conditions, and secondary natural disturbances such as insect outbreaks (Kenkel et al. 1997; Bergeron 2000; Peters et al. 2005, 2006). Overall, the diversity and complexity of these factors result in a wide variety of possible pathways of stand structures and compositions (Fig. 3 and Fig. 4).

\section{The role of fire in stand initiation}

The natural disturbance regime of the boreal mixedwood is dominated by stand-initiating wildfire (Johnson 1992). Wildfires remove vegetation, reduce the depth of the forest floor, and increase light and nutrient availability to the benefit of early-establishing herbs, shrubs and trees (Chen and Popadiouk 2002, Purdy et al. 2002, Greene et al. 2007). Forest composition following wildfire is strongly influenced by pre-fire species composition and the severity, size and return interval of the fire itself (Johnson 1992; Johnstone and Chapin 2006a, 2006b). When young stands burn, they have a much higher probability of regenerating to broadleaf dominance than do mature stands (Johnstone and Chapin 2006b) and frequent fire increases the abundance of broadleaf species at the expense of conifers (Dix and Swan 1971, Chen et al. 2009). Species with serotinous cones, such as jack pine and black spruce, are promoted by fire and will show general stand self-replacement stand dynamics provided that fires are sufficiently frequent and recurrent (Rowe and Scotter 1973, Ilisson and Chen 2009a). Fire affects both propagule availability and regeneration substrate suitability, which in turn regulate regeneration and subsequent stand dynamics (Kruger and Reich 1997; Johnstone et al. 2004; Johnstone and Chapin 2006a, 2006b).

\section{The influence of species' regeneration strategies and life history traits}

Patterns of stand dynamics are a function of the characteristics of each species-such as shade-tolerance, regeneration niche, and longevity-interacting with the effects of the fire and with other biotic and abiotic factors (Fig. 2). Differences in regeneration, tolerance, growth and the timing of senescence regulate post-disturbance establishment and regeneration following secondary disturbances, and thus the nature and timing of any shifts in species composition (Fig. 3 and Fig. 4).

Immediate post-fire regeneration sets the template for longterm stand dynamics. Forest re-establishment after disturbance requires a source of seeds or vegetative propagules (buds). Fire size and severity influence distance to seed sources (unburned residuals and the surrounding landscape) and thus the possibilities for colonization. The common boreal broadleaf species, particularly aspen and balsam poplar (Populus balsamifera L.), undergo rapid post-fire clonal regeneration from root suckers (Schier 1973, Frey et al. 2003). Post-fire regeneration of these species is therefore strongly related to pre-fire composition (Johnstone and Chapin 2006b, Chen et al. 2009, Ilisson and Chen 2009a). Adaptations such as cone serotiny in jack pine (Pinus banksiana Lamb.), lodgepole pine (Pinus contorta Loud.) and black spruce (Picea mariana [Mill.] BSP.), and masting in white spruce (Picea glauca [Moench] Voss), also strongly influence post-fire seed availability (Greene et al. 1999, Peters et al. 


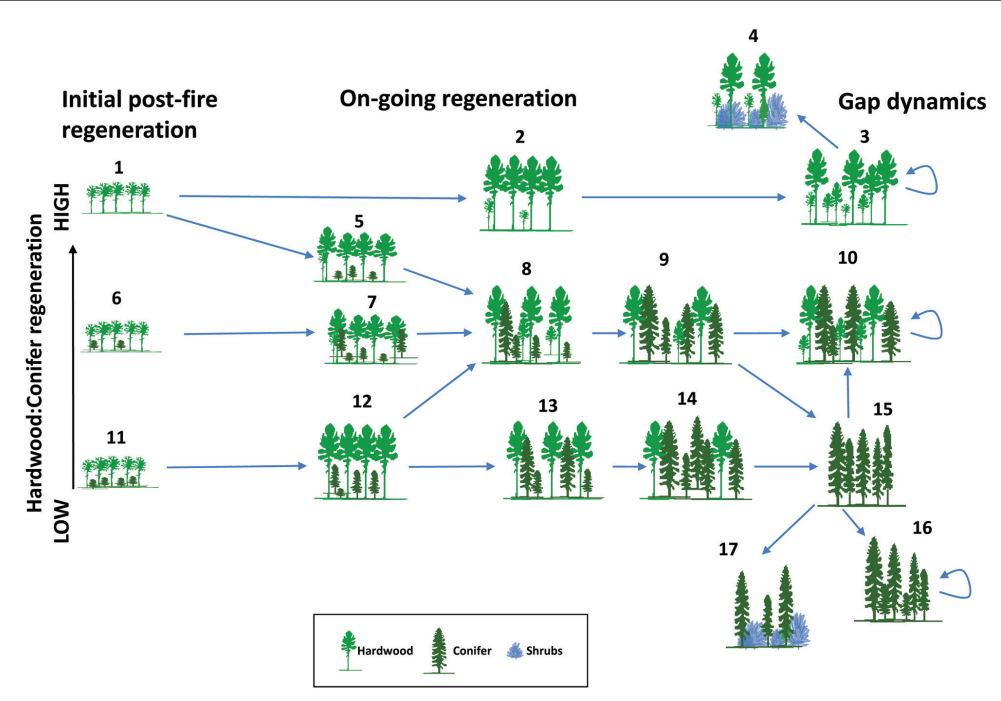

Fig. 3. Generalized patterns of mixedwood stand dynamics as a function of the amount of broadleaf and conifer regeneration in the initial post-fire period and later on during stand development, as well as the influence of canopy senescence and secondary disturbances. The six stand dynamics patterns described in the text are represented by the following transitions between forest conditions: 1) "classic": 6-7-8-9-15-16 or 11-12-13-14-15-16, 16 gap dynamics; 2) No conifer regeneration: 1-2-3, 3 gap dynamics; 3) Ongoing broadleaf and conifer regeneration: 1-5-89-10 or 6-7-8-9-10, 10 gap dynamics; 4) Accelerated transition to conifer: same as (1) except faster; 5) Ongoing broadleaf recruitment: 15-10, 10 gap dynamics; 6) Transition to shrub dominance: 3-4 or 15-17.

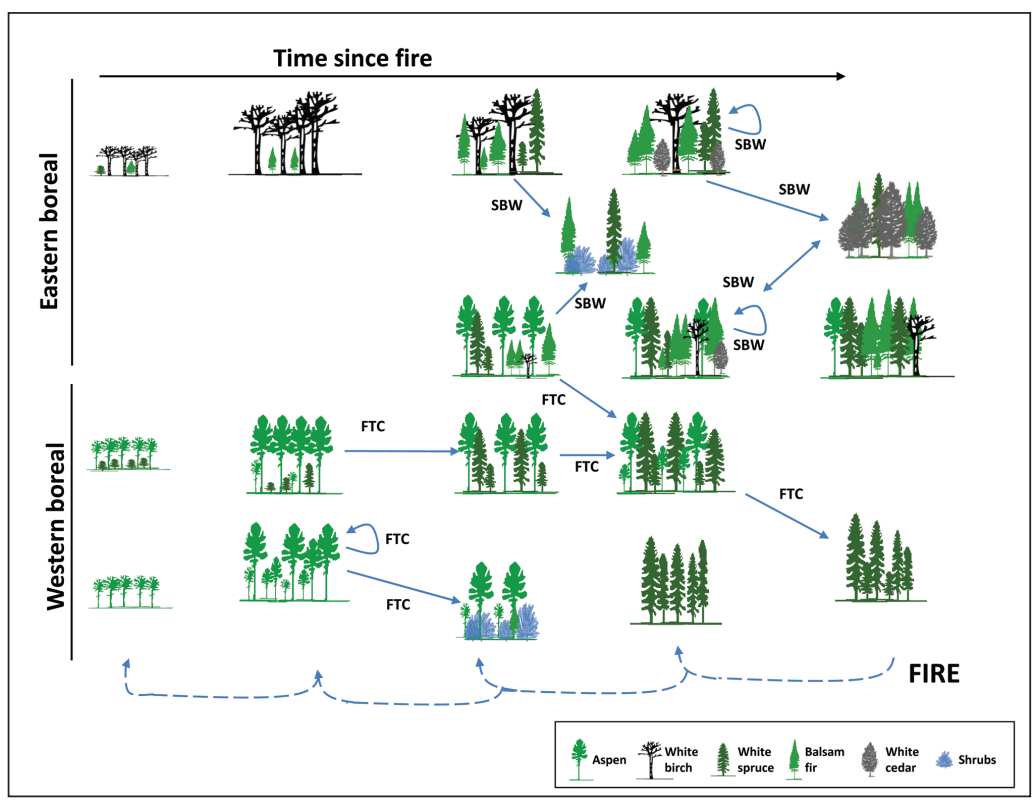

Fig. 4. The main species and conditions of forest structure and composition at various stages of boreal mixedwood stand dynamics in the eastern and western boreal in Canada and the role of secondary disturbance in driving stand dynamics. Spruce budworm (SBW), forest tent caterpillar (FTC) and other secondary disturbances drive transitions in canopy composition and gap dynamics (as discussed in the text); fire resets the system to a younger condition.

2005). Regeneration of later-colonizing conifers is primarily from seeds germinating on rotting logs, but vegetative layering may also be important (Bergeron 2000).

The regeneration microsite has an important controlling influence on the success of conifer regeneration, both immediately post-fire and later in stand development (Simard et al. 1998, 2003; Peters et al. 2006). Conifer regeneration is strongly dependent on the availability of suitable microsites. White spruce germinates best on exposed mineral soil, a thin organic layer, or well-decayed wood (Purdy et al. 2002, Peters et al. 2006) while white cedar prefers decaying wood (Simard et al. 1998, 2003). All conifer seedlings, with the possible exception of balsam fir, have difficulty establishing in leaf litter (Simard et al. 1998, 2003). Fire severity strongly regulates the availability of regeneration microsites and thus has an important controlling influence on the density of initial conifer regeneration (Charron and Greene 2002, Johnstone and Chapin 2006a, Greene et al. 2007). Fire severity, through its influence on propagule availability and microsites, can also influence vegetative regeneration or seedling establishment in broadleaf species such as aspen (Frey et al. 2003; Greene et al. 2004, 2005; Landhäusser et al. 2010).

Ongoing tree recruitment-or lack thereof-influences species composition throughout stand development (Fig. 3). For example, the timing of post-fire regeneration by white spruce can strongly affect mixedwood composition (e.g., Peters et al. 2006). If conifer regeneration is poor, due to seed or microsite limitations or canopy competition, broadleaf stands may be maintained as such across fire cycles (Dix and Swan 1971, Chen and Popadiouk 2002, Johnstone and Chapin 2006b). Vegetative reproduction (via layering) in boreal conifers can also be an influential process at the later stage of stand development (Bergeron 2000).

Ongoing recruitment of white spruce and balsam fir seedlings most commonly occurs on partially decomposed logs, since elevated logs provide some protection from pathogens (Zhong and van der Kamp 1999), competing herbaceous vegetation, and smothering leaf litter (Lieffers et al. 1996b; Simard et al. 1998, 2003; Awada et al. 2004). The establishment and growth of advance regeneration is largely related to light and moisture availability (Zasada et al. 1992). Tree recruitment is often limited by competition with grasses, forbs or shrubs (Zoladeski and Maycock 1990). A dense understory of beaked hazelnut (Corylus cornuta Marsh.) reduces aspen root suckering after disturbance (Mundell et al. 2007) and strongly inhibits the recruitment of conifers (Waldron 1959, Trottier 1981). In the east, mountain maple (Acer spicatum Lamb.) competes with balsam fir in gaps formed by spruce budworm, reducing the quantity and height of fir saplings (Kneeshaw and Bergeron 1996). Aspen regeneration is also negatively affected by grass competition (Landhäusser and Lieffers 1998, Landhäusser et al. 2007).

Species differences in growth rate and longevity also regulate perceived patterns of stand dynamics. Shade-tolerant conifers 
typically have slower initial growth rates than do shade-intolerant broadleaf species (Frelich and Reich 1995, Lieffers et al. 1996b, Chen and Popadiouk 2002, Gutsell and Johnson 2002). The faster growth of these early-colonizing broadleaf trees allows them to quickly dominate the forest canopy. However, these species generally have a shorter lifespan, reaching the age of senescence sooner than slower-growing conifers (Auger et al. 2004, Bergeron 2000). Canopy openings created through the senescence and death of the early-colonizing broadleaf species result in the establishment or release of more shade-tolerant, slower-growing conifers (Kneeshaw and Bergeron 1996, Bergeron 2000, Brassard and Chen 2006). Self-replacement can also occur, however, in which broadleaf species re-establish themselves in canopy openings through successful root suckering (Bergeron 2000, Cumming et al. 2000, Senecal et al. 2004, Kurkowski et al. 2008).

The age of tree senescence, and therefore of compositional transitions in mixedwoods, is dependent on site quality and climate and thus varies among regions (Kabzems and Garcia 2004). For example, aspen and jack pine show earlier senescence on more fertile sites (Auger et al. 2004, Duchesne and Ouimet 2009) while aspen decline in Alberta occurs more rapidly on poor sites (Meng et al. 2008). The age of onset and duration of senescence of some species, including jack pine, increases at more northerly latitudes (Pothier and Savard 1998).

The influence of non-stand replacing (secondary) disturbances Secondary disturbances are important drivers for stand dynamics. We can divide secondary disturbances into patch (landscape scale) and gap (within-stand scale) disturbances as a function of the area affected.

The most important patch disturbance driving mixedwood stand dynamics is defoliation by insects (Fig. 4). Indeed, insect outbreaks may be a more important driver of forest composition in older stands than time since fire (Taylor and Chen 2011). The impact of insect defoliation on tree regeneration and the soil organic layer is typically less severe than wildfire. Furthermore, insect outbreaks affect forest stands in a species-specific way, and their influence often extends over several years (Baskerville 1975, McCullough et al. 1998, Chen and Popadiouk 2002). The two most disruptive insect defoliators in the Canadian boreal forest are spruce budworm (Choristoneura fumiferana Clemens, SBW), which feeds mostly on balsam fir and spruces, and forest tent caterpillar (Malacosoma disstria Hübner; FTC), which affects mainly trembling aspen, balsam poplar and paper birch (Batzer and Morris 1978, Moulinier et al. 2011, Chen and Taylor 2012).

The effects of spruce budworm are key to understanding eastern boreal forest dynamics (Morin 1994, Bouchard et al. 2006) (Fig. 4). Spruce budworm outbreaks occur over a period of several years, oftentimes over areas much larger than those affected by fire (Blais 1983, Morin et al. 1993, Candau et al. 1998). Spruce budworm mainly affects mature to over-mature balsam fir stands, and outbreaks are responsible for the formation of canopy gaps in these stands (Morin 1994, Bergeron et al. 1995). Their impact is, however, less in young stands or landscapes with a higher broadleaf component (Bergeron et al. 1995, Su et al. 1996, Kneeshaw and Bergeron 1998, Colford-Gilks et al. 2012). Host trees show an appreciable decline in growth rate when undergoing insect attack (MacKinnon and MacLean 2004), and repeated defoliation results in mortality (Bergeron et al. 1995). Suppressed balsam fir saplings show release growth following an outbreak, especially in immature stands (Kneeshaw and Bergeron 1998). While white spruce is less affected by spruce budworm than balsam fir (MacLean and MacKinnon 1997), it shows poorer post-outbreak recovery (Kneeshaw and Bergeron 1996). The effects of spruce budworm outbreaks are dependent on site conditions and the pre-existing composition and structure of both the stand and the surrounding landscape (MacLean and MacKinnon 1997, 2004; Campbell et al. 2008; Colford-Gilks et al. 2012). In balsam fir-dominated stands, spruce budworm outbreaks often result in a continuous cycle of fir dominance (Baskerville 1975, Pham et al. 2004). Alternatively, spruce budworm outbreaks may favor the recruitment of shade-intolerant species, resulting in conifer-dominated stands reverting to mixedwood stands (Kneeshaw and Bergeron 1998, Chen and Taylor 2012).

The forest tent caterpillar is a known defoliator of broadleaf species, particularly aspen (Cooke and Lorenzetti 2006). Outbreaks of this insect cause substantial and sustained reduction in leaf area and live crown volume in aspen stands and slow the radial growth of trees (Cooke and Roland 2007, Sutton and Tardif 2007, Moulinier et al. 2011). At the landscape scale, forest tent caterpillar outbreaks show strong periodicity with peak outbreaks being decadal and usually lasting less than five years; however, at a more local scale outbreaks can be more frequent and/or last for as long as a decade (Cooke and Roland 2007). Repeated and severe defoliation in aspen stands increases mortality of mature stems and may accelerate the decline of older stands (Ghent 1958, Chen and Popadiouk 2002, Man and Rice 2010). The thinning effect of forest tent caterpillar defoliation may facilitate the release of shade-tolerant conifer species such as spruce or fir, speeding their growth into the canopy (Ghent 1958, Man and Rice 2010). Alternatively, canopy gaps may be large enough to allow for the self-replacement of trembling aspen from root suckers (Kneeshaw and Bergeron 1998, Man and Rice 2010, Moulinier et al. 2011, Reinikainen et al. 2012). Although less frequent than insect disturbance, major windthrow events are another patch disturbance observed in mixedwood forests (Peterson 2004, Bouchard et al. 2009).

Forest dynamics are also influenced by smaller-scale gap disturbances such as single-tree blowdowns, pathogens, and other insects or herbivores. Tree deaths creating gaps are often the result of a combination of these factors. For example, older trees already weakened by insects and fungi are much more susceptible to blowdown (Taylor and Maclean 2005, 2007; Rich et al. 2007). Blowdown is more likely in trees with large crownsbecause of the increased contact surface with the wind-and a shallow root system, particularly when growing on shallow soil (Peterson 2004, Kneeshaw et al. 2011). Blowdown mortality creates canopy openings that facilitate the release of suppressed trees and provide an opportunity for stand regeneration (Morin 1994, Ruel 1995).

Herbivory by mammals, including ungulates (moose $(\mathrm{Al}$ ces americanus Clinton), elk (Cervus canadensis L. ) and deer (Odocoileus virginianus Zimmermann)), hares (Lepus americanus Erxleben) and beaver (Castor canadensis Kuhl) also directly impacts stand dynamics (e.g., Pastor and Naiman 1992). As with insects, herbivore effects are species-specific. For example, moose selectively browse balsam fir saplings in the winter months (Belovsky 1981). Repeated and regular browsing of balsam fir saplings by ungulates has been shown to greatly reduce recruitment of fir into the canopy, in both eastern and western boreal forests (Brandner et al. 1990, Potvin et al. 2003). Moose 
and elk also browse aspen (Pastor et al. 1993, Rounds 1979), which can result in the creation of persistent gaps in aspen stands in western boreal forest (MacIsaac et al. 2006). Browsing by snowshoe hares on white spruce seedlings reduces growth and causes mortality (Cater and Chapin 2000, Peters 2002). Beaver can also greatly reduce the density of trembling aspen through their foraging and dam-building activities (Rosell et al. 2005). The large canopy openings resulting from beaver activity may accelerate the development of conifer stands, or alternatively provide an opportunity for aspen self-replacement (Johnston and Naiman 1990, Donkor and Fryxell 1999). The differential effect of browsing can result in divergence in stand structure and composition over time (Johnston and Naiman 1990, Pastor and Naiman 1992, Pastor et al. 1993, Donkor and Fryxell 1999).

\section{Patterns of Mixedwood Stand Dynamics}

Given the complex interacting effects of disturbance (including type, size, frequency and intensity), seed and bud source availability, seed dispersal, seedbed quality, competition, climatic, edaphic and topographic variability, insect pests, fungal pathogens and herbivory, it is not surprising that mixedwood boreal forests display a wide variety of pathways (Cattelino et al. 1979, Bergeron and Dubuc 1989, Caners and Kenkel 2003, Kurkowski et al. 2008, Taylor and Chen 2011). Throughout the boreal mixedwood, there is considerable variation on the "classical" mixedwood forest dynamic model (Chen and Popadiouk 2002).

The relative abundance of broadleaf versus conifer regeneration immediately post-fire, together with the amount of ongoing regeneration of broadleaf and conifer species, are key factors underlying variation in patterns of mixedwood stand dynamics (Fig. 3). Broadleaf and conifer species often establish contemporaneously following a disturbance but constant recruitment of conifer in the understory is also often observed, especially in the eastern portions of the mixedwood region. Changes in canopy dominance over time reflect the rate at which post-disturbance broadleaf forests are invaded by conifers (Lieffers et al. 1996b, Galipeau et al. 1997, Albani et al. 2005, Kabzems and Garcia 2004, Peters et al. 2006) and differences in the growth rates and longevity of species (Cogbill 1985, Bergeron and Charron 1994, Gutsell and Johnson 2002, Johnstone et al. 2004, Kabzems and Garcia 2004, Peters et al. 2006). Considerable variation in these processes drives variation in mixedwood stand dynamics.

At a landscape scale, composition changes are predictable for a long period after fire, but the time required for compositional changes to occur can vary widely from one landscape to another (e.g., Frelich and Reich 1995). At smaller spatial scales canopy dynamics are highly variable, even under similar abiotic conditions (Bergeron and Charron 1994, Frelich and Reich 1995; Fig. 3 and Fig. 4). With prolonged absence of stand-replacing disturbance, successional pathways are numerous and regulated by neighbourhood effect, availability of resources, and secondary disturbances (Morin et al. 1993, Kneeshaw and Bergeron 1998, Pham et al. 2004, Amos-Binks et al. 2010, Taylor and Chen 2011).

We describe six possible stand dynamic pathways in boreal mixedwood forests, which arise as a result of differences in immediate post-fire floristics, ongoing regeneration, and effects of secondary disturbances (Fig. 3). All of these possible trajectories are empirically evident-at least at the plot or stand level-in both eastern and western boreal mixedwoods, although the predominant species and disturbance effects vary among regions (Fig. 4). At the landscape scale, this diversity in stand dynamic trajectories results in the long-term maintenance of mixedwoods (i.e., long-term coexistence of broadleaf and conifer species) under most conditions.

\section{Classical dynamics}

The classical pattern of post-fire mixedwood dynamics is the "three cohort" model (Bergeron 2000, Chen and Popadiouk 2002), in which forests gradually transition from broadleaf dominance (aspen and paper birch), to mixed stands with an important conifer component, and eventually to conifer stands dominated by spruce (black or white, depending on soil conditions), balsam fir or white cedar (Fig. 3). Following fire, mixedwood forests are typically initially dominated by shadeintolerant broadleaf species such as aspen and paper birch. Several studies have shown that, given sufficient time without a major disturbance, the more shade-tolerant conifers eventually replace the pioneer broadleaf species in the canopy (Carleton and Maycock 1978, Bergeron and Dubuc 1989, Frelich and Reich 1995, De Grandpré et al. 2000, Duchesne and Ouimet 2009, Kurkowski et al. 2008). Senescence of the initially dominant broadleaf canopy (Pothier et al. 2004) allows replacement by slower-growing, shade-tolerant species found beneath the canopy (Kneeshaw and Bergeron 1996, Bergeron 2000). The timing of this transition can be highly variable, depending on vigour and longevity of the broadleaf canopy (Kabzems and Garcia 2004) and the timing of conifer regeneration post-disturbance (Peters et al. 2006).

In the eastern boreal mixedwood, both paper birch and aspen are important shade-intolerant pioneers, while balsam fir, black spruce, white spruce and white cedar are the most important canopy-replacing conifer species (Bergeron and Dubuc 1989, Bergeron 2000, De Grandpré et al. 2000; Fig. 4). However, eastern white cedar is absent from the western boreal region and balsam fir is much less abundant in the west (Lenihan 1993). Balsam fir is typically slow to establish in western mixedwood stands (Dix and Swan 1971). A combination of more frequent fires and drier and colder climatic conditions likely limits the distribution and abundance of balsam fir in the western boreal mixedwood forest (Moss 1953, Rowe 1961, Lenihan 1993). Thus, boreal mixedwoods in western Canada primarily are comprised of trembling aspen and white spruce (Fig. 4).

In the absence of a stand-initiating disturbance, forest structure and composition are regulated by gap dynamics (Frelich and Reich 1995, Kenkel et al. 1997, Römer et al. 2007, Kneeshaw et al. 2011). In the eastern boreal forest, where a lower fire frequency allows sufficient time for stands to experience canopy disturbance, shade-tolerant species recruit into gaps and forests develop a multi-cohort structure with a mosaic canopy of conifer species such as balsam fir or eastern white cedar (Frelich and Reich 1995, McCarthy 2001, Chen and Popadiouk 2002, Pham et al. 2004). In the presence of a white cedar seed source and abundant dead wood-the preferred regeneration substrate for white cedar (Simard et al. 1998, 2003; Asselin et al. 2001)_eastern boreal stands may eventually be dominated by this long-lived species and remain stable until the next stand-initiating fire (Bergeron and Dubuc 1989, Bergeron 2000, Taylor and Chen 2011). In the western boreal, however, the higher fire frequency results in a smaller proportion of broadleaf or mixedwood stands transitioning to conifer dominance. 
No conifer regeneration: constant broadleaf dominance and multi-aged aspen stands

The classical pattern is dependent on the presence, often suppressed under the broadleaf canopy, of abundant conifer regeneration that is necessary to ensure temporal transitions in canopy composition. A self-replacing pathway occurs when canopy dominance by pioneer species is maintained beyond the initial cohort stage (Cumming et al. 2000, Kurkowski et al. 2008). This dynamic is characteristic of stands that lack a local seed source of shade-tolerant conifers (Bergeron and Dubuc 1989, Bergeron 2000, Caners and Kenkel 2003, Johnstone et al. 2004). Several studies have shown that frequent and severe natural disturbances can result in the local extirpation of conifer species (Moss 1953, Dix and Swan 1971, Bergeron and Dubuc 1989, Johnstone and Chapin 2006b). Other studies have established that the main factors responsible for absence of conifer species in some stands are seed or seedbed limitations (Galipeau et al. 1997, Stewart et al. 1998, Purdy et al. 2002, Peters et al. 2005) or poor establishment and survival of conifer seedlings beneath a broadleaf canopy (DeLong et al. 1997, Greene et al. 1999, Simard et al. 2003, Albani et al. 2005, Gärtner et al. 2011). In these situations, senescence of the broadleaf canopy can result in ongoing root sucker regeneration, creating a selfreplacing gap dynamic stand (Cumming et al. 2000, Caners and Kenkel 2003). Forest tent caterpillar outbreaks can facilitate this type of dynamic, by producing canopy gaps of sufficient size to permit broadleaf regeneration and subsequent development of uneven-aged aspen stands (Moulinier et al. 2011). This dynamic is more important in western regions, where fires were historically of sufficient frequency to ensure that stands burned before changes in canopy composition could occur (Dix and Swan 1971, Zoladesky and Maycock 1990, Johnson 1992, Youngblood 1995, Gutsell and Johnson 2002, Johnstone et al. 2004). However, this type of stand dynamics pathway also exists in eastern boreal forests, and may be more important than previously recognized (Zoladeski and Maycock 1990, Kneeshaw and Gauthier 2003, Moulinier et al. 2011).

\section{Ongoing recruitment of both broadleaf and conifer: multi-aged mixedwood}

In the western boreal, older mixedwood stands are perpetuated through the ongoing recruitment of both trembling aspen and white spruce, with lesser amounts of balsam poplar and paper birch (Rowe 1961, Caners and Kenkel 2003, Awada et al. 2004, Levac 2012, Reinikainen et al. 2012). This long-term coexistence of trembling aspen and white spruce as a self-replacing mixed mosaic may be attributable to the absence of white cedar, together with limited recruitment of balsam fir over much of the western boreal forest (Moss 1953, Dix and Swan 1971). Unlike balsam fir, white spruce rarely forms extensive, dense monospecific stands. The long-term co-existence of trembling aspen and white spruce is attributable to the ability of both species to successfully colonize gaps created by secondary disturbances (Cumming et al. 2000, Senecal et al. 2004).

This dynamic is also evident in the eastern boreal. Both aspen and birch, along with conifers, can invade canopy gaps at later stages of stand development (Chen and Taylor 2012). Substantial increases in the abundance of broadleaf trees following secondary disturbances create multi-aged mixedwoods, and severe spruce budworm outbreaks can even result in birch dominance (Taylor and Chen 2011).
Accelerated replacement by conifers: rapid mixedwood to conifer transition

The classical pathway can be accelerated by secondary disturbances. Stand dynamics following a small-scale disturbance depend on the regeneration already present. In stands with abundant white spruce regeneration, a forest tent caterpillar outbreak that thins the broadleaf canopy can facilitate a more rapid transition to mixedwood stands and eventual conifer dominance (Ghent 1958, Man and Rice 2010, Reinikainen et al. 2012). Similarly, removal of the aspen canopy through windthrow or disturbance by beavers could accelerate the release and recruitment of conifers such as white spruce and white cedar (Johnston and Naiman 1990, Rich et al. 2007). When balsam fir saplings are abundant, a spruce budworm outbreak could speed transition to a self-replacing stand of balsam fir (Baskerville 1975) but with insufficient fir regeneration the stand could transition to white cedar dominance (Frelich and Reich 1995, Bergeron 2000, Taylor and Chen 2011).

\section{Ongoing broadleaf recruitment in gaps: later transition from conifer-dominance to mixedwood}

In the absence of sufficient conifer regeneration, disturbance to an existing conifer-dominated canopy could result in the regeneration of broadleaf species. The conifer stand could then transition to a mixedwood condition and be maintained as such, displaying mixedwood gap dynamics (Kneeshaw and Bergeron 1998, Senecal et al. 2004, Römer et al. 2007, Reinikainen et al. 2012). Spruce budworm defoliation or windthrow could be causal factors producing this dynamic (Taylor and Chen 2011, Reinikainen et al. 2012).

\section{Broadleaf or conifer dominance to shrub dominance}

If there is little advanced conifer regeneration, competition from shrubs (beaked hazel in the west, mountain maple and beaked hazel in the east) or grasses (e.g., Calamagrostis canadensis [Michx.] Nutt.) can severely hamper ongoing tree seedling regeneration, slowing or inhibiting the transition from broadleaf to conifer dominance (Kneeshaw and Bergeron 1998, Landhäusser and Lieffers 1998). Some studies have shown that broadleaf- or conifer-dominated stands can develop into shrubby, open-canopy stands as natural mortality removes canopy trees (Zoladeski and Maycock 1990, Caners and Kenkel 2003, Reinikainen et al. 2012). High shrub abundance can significantly reduce light at ground level, limiting tree regeneration and recruitment even if canopy openings are present (Kurmis and Sucoff 1989; Kneeshaw and Bergeron 1996, 1998; Messier et al. 1998). If shrub cover persists this dynamic results in reduced forest productivity, although productive stands are expected to redevelop following a stand-replacing disturbance.

\section{Implications for Management}

Overall, boreal mixedwood forest stand dynamics are characterized by a shifting spatio-temporal dynamic including many different possibilities for transitions in canopy composition, or lack thereof. The classic canopy transition from a broadleaf canopy to mixedwoods and then to conifer dominance may be common, but each of these forest types could remain as such, i.e., developing into a multi-cohort stand displaying gap dynamics. Also, conifer-dominated stands can develop into mixedwoods, and either conifer or broadleaf forests could evolve to shrub-dominated communities. There is considerable 
evidence for all these possibilities in the east (e.g., Senecal et al. 2004, Römer et al. 2007, Taylor and Chen 2011), and in Manitoba (Levac 2012) and Alberta (Shongming Huang, Alberta Environment and Sustainable Resource Development, personal communication, the "dynamic alternating moving mosaic") as well.

It is challenging to maintain this complexity of dynamics in a forest management context. Yet there are multiple advantages to managing to maintain mixedwoods at both the stand and landscape scales, including maintaining biodiversity (Cavard et al. 2011), improving tree growth and forest productivity (Man and Lieffers 1999, Chen et al. 2003, Zhang et al. 2012), reducing the risk of insect and pathogen outbreaks (Cappuccino et al. 1998; MacKinnon and Maclean 2003, 2004; Colford-Gilks et al. 2012; Nixon and Roland 2012) and fire (Cumming 2001, Hirsch et al. 2001), and improving resilience to climate change (Drobyshev et al. 2012, Terrier et al. 2013). Variation in stand-level composition underlies landscape-scale diversity in boreal mixedwood forest composition (Frelich and Reich 1995). The diversity of patterns in mixedwood stand dynamics is a function of a set of basic ecological drivers: 1) regional differences in climate and edaphic conditions; 2) fire and non-stand-replacing disturbances; 3 ) propagule (species pool) availability and species trait variation; 4) microsite variation; and 5) time since stand-replacing disturbance. Complexity emerges not only at the stand scale, where different mixtures are observed, but also at the landscape scale where the spatio-temporal mosaics are controlled by variation in the size and frequency of fires.

To move forward towards sustainable management of boreal mixedwoods, we recommend the following principles. We can focus on processes underlying the complexity of patterns and the silvicultural options required to emulate them (e.g., Lieffers et al. 1996a, Puettmann et al. 2009, Taylor et al. 2009; Table 2). Such management practices should be region- and objective-specific. Variation in these drivers has resulted in the very high diversity of forest stands within and among regions; "one size fits all" management will inevitably reduce diversity and stand dynamics of Canada's boreal mixedwood forests (Macdonald 1995, Bergeron and Harvey 1997, Burton et al. 2006, Lieffers et al. 2008, Messier et al. 2013). In light of increased natural and human disturbances (CCFM 2008, Fauria and Johnson 2008), both of which promote broadleaf trees at the expense of conifers (Ilisson and Chen 2009b), we need approaches to forest management that can facilitate maintenance of mixedwood composition.

There are many ways in which silviculture could be used to help maintain regional mixedwood complexity. Giving specific guidelines goes beyond the scope
Ongoing regeneration of broadleafs and conifers

Small-scale canopy disturbance

Transitions in canopy composition

Gap dynamics

Stand re-initiation

of this paper, but Table 2 presents the main driving factors and processes underlying mixedwood stand dynamics and provides suggestions for management options that could be further developed in the future. In the east, studies on disturbance and stand dynamics were used in the development of an ecosystem management approach for the Lake Duparquet Research and Teaching Forest (Bergeron and Harvey 1997, Bergeron et al. 1999, Harvey et al. 2002). A silvicultural system inspired by natural dynamics, in which fire is emulated by clearcutting and natural canopy succession is imitated by partial cutting, was developed. Even-aged stands dominated by broadleaf species but with an understory of conifers are partially cut in order to reproduce the natural death of trees observed through the succession towards mixed broadleaf/conifer stands. These stands can be partially cut again to produce pure conifer stands. A proportion of broadleaf, mixed and conifer stands are clearcut in order to emulate fire disturbances. Mortality due to insect outbreaks and gap dynamics (Kneeshaw and Bergeron 1998) that occur in late successional conifer stands could also be emulated using partial and selection cutting. At the landscape level, the proportion of stands belonging to broadleaf, mixed and conifer compositions are quantified in order to represent the proportion that would be observed under a natural disturbance regime. Although the implementation of this approach is relatively recent, results are encouraging (Brais et al. 2004, Gendreau-Berthiaume et al. 2012). Similar approaches are currently being developed elsewhere in Canada (Lieffers et al. 1996a, Taylor et al. 2009, Gärtner et al. 2011; see The Forestry Chronicle Vol. 90, No. 1).

Through this analysis of process and pattern, we aimed to create a common understanding of the complexity of stand dynamics in Canadian boreal mixedwoods and to highlight

Table 2. Key ecological processes underlying the diversity in mixedwood stand dynamics and management options to emulate them.

\begin{tabular}{ll} 
Ecological process/driver & Management option \\
\hline $\begin{array}{l}\text { Density of post-disturbance } \\
\text { broadleaf and conifer } \\
\text { regeneration }\end{array}$ & $\begin{array}{l}\text { Planting } \\
\text { Harvesting practices and silviculture to encourage natural } \\
\text { regeneration } \\
\text { Regeneration standards allowing intimate mixtures } \\
\text { Manage microsite conditions post-harvesting (e.g., } \\
\text { minimize physical site damage such as rutting and } \\
\text { compaction that does not occur following natural } \\
\text { disturbances) }\end{array}$
\end{tabular}

Facilitating natural regeneration through thinning, gap creation or site preparation

Maintaining a legacy of regeneration microsites (e.g., downed dead wood)

Underplanting conifers

Thinning, patch or other partial harvesting

Selective harvesting (e.g., understory retention) Longer rotation, 3-cohort (broadleaf, mixedwood, conifer) approach

Longer rotation, 3-cohort approach Partial harvesting to encourage broadleaf or conifer regeneration

Clearcut harvesting or partial harvesting with low levels of retention 
common drivers. The next steps involve incorporation of this understanding into forest harvest models, and the development of management systems that can reproduce this complexity at both the stand and landscape scales. A comprehensive costbenefit analysis of these approaches is also needed.

\section{Acknowledgements}

We are very grateful to Ken Baldwin (Natural Resources Canada) for providing the map shown in Fig. 1. We thank the organizing committee of the conference: Boreal Mixedwoods 2012: Ecology and Management for Multiple Values, June 17-20, 2012; Edmonton, AB. for the invitation to speak on this topic, thus inspiring this collaborative effort. We also thank anonymous reviewers who contributed to improvement of the manuscript.

\section{References}

Albani, M., D.W. Andison and J.P. Kimmins. 2005. Boreal mixedwood species composition in relationship to topography and white spruce seed dispersal constraint. For. Ecol. Manage. 209: 167-180.

Amos-Binks, L.J., D.A. MacLean, J.S. Wilson and R.G. Wagner. 2010. Temporal changes in species composition of mixedwood stands in northwest New Brunswick: 1946-2008. Can. J. For. Res. 40: 1-12.

Asselin, H., M.J. Fortin and Y. Bergeron. 2001. Spatial distribution of late-successional coniferous species regeneration following disturbance in southwestern Quebec boreal forest. For. Ecol. Manage. 140: 29-37.

Auger, I. et al. 2004. Détermination de lâge approximatif d’entrée en sénescence des principaux peuplements forestiers à l'aide des placetteséchantillons temporaires. Ministère des Ressources naturelles de la Faune et des Parcs, Québec.

Awada, T., G.M. Henebry, R.E. Redmann and H. Sulistiyowati. 2004. Picea glauca dynamics and spatial pattern of seedlings regeneration along a chronosequence in the mixedwood section of the boreal forest. Ann. For. Sci. 61: 789-794.

Baldwin, K.A., W.H. MacKenzie, J. Pfalz, W.J. Meades, D.V. Meidinger, A. Robitaille, J.-P. Saucier and P. Uhlig. 2012. Level 4 map, version 1, Canadian component of the Circumboreal Vegetation Map (CBVM). Canadian regional team of the Circumboreal Vegetation Map Project. Natural Resources Canada, Canadian Forest Service, Great Lakes Forestry Centre, Sault Ste. Marie, ON. Unpublished map.

Bartels, S. F. and H.Y.H. Chen. 2012. Interactions between overstorey and understorey vegetation along an overstorey compositional gradient. J. Veg. Sci. doi: 10.1111/j.1654-1103.2012.01479.x

Baskerville, G.L. 1975. Spruce budworm: super silviculturalist. For. Chron. 51: 138-140.

Batzer, H.O. and R.C. Morris. 1978. Forest tent caterpillar. US Dept. of Agriculture, Forest Service. Forest Insect and Disease Leaflet No. 9.

Belovsky, G.E. 1981. Food plant selection by a generalist herbivore: the moose. Ecology 62: 1020-1030.

Bergeron, Y. 2000. Species and stand dynamics in the mixed woods of Quebec's southern boreal forest. Ecology 81: 1500-1516.

Bergeron, Y. and D. Charron. 1994. Postfire stand dynamics in a southern boreal forest (Québec): a dendroecological approach. Écoscience 1: 173-184.

Bergeron, Y. and P.R. Dansereau. 1993. Predicting the composition of Canadian southern boreal forest in different fire cycles. J. Veg. Sci. 4: 827-832.

Bergeron, Y. and M. Dubuc. 1989. Succession in the southern part of the Canadian boreal forest. Plant Ecol. 79: 51-63.

Bergeron, Y. and N.J. Fenton. 2012. Boreal forests of eastern Canada revisited: old growth, nonfire disturbances, forest succession, and biodiversity. Botany 90: 509-523.

Bergeron, Y. and B. Harvey. 1997. Basing silviculture on natural ecosystem dynamics: An approach applied to the southern boreal mixedwood forest of Quebec. For. Ecol. Manage. 92: 235-242.
Bergeron, Y., B. Harvey, A. Leduc and S. Gauthier. 1999. Basing forest management on natural disturbance: Stand- and landscape-level considerations. For. Chron. 75: 49-54.

Bergeron, Y., A. Leduc, H. Morin and C. Joyal. 1995. Balsam fir mortality following the last spruce budworm outbreak in northwestern Quebec. Can. J. For. Res. 25: 1375-1384.

Blais, J.R. 1983. Trends in the frequency, extent, and severity of spruce budworm outbreaks in eastern Canada. Can. J. For. Res. 13: 539-547.

Bouchard, M., D. Kneeshaw and Y. Bergeron. 2006. Forest dynamics after successive spruce budworm outbreaks in mixedwood forests. Ecology 87: 2319-2329.

Bouchard, M. and D. Pothier. 2008. Simulations of the effects of changes in mean fire return intervals on balsam fir abundance, and implications for spruce budworm outbreaks. Ecol. Model. 218: 207-218.

Bouchard, M., D. Pothier and S. Gauthier. 2008. Fire return intervals and tree species succession in the North Shore region of eastern Quebec. Can. J. For. Res. 38: 1621-1633.

Bouchard, M., D. Pothier and J.-C. Ruel. 2009. Stand-replacing windthrow in the boreal forests of eastern Quebec. Can. J. For. Res. 39: 481-487.

Brais, S., B.D. Harvey, Y. Bergeron, C. Messier, D. Greene, A. Belleau and D. Paré. 2004. Testing forest ecosystem management in boreal mixedwoods of northwestern Québec: initial response of aspen stands to different levels of harvesting. Can. J. For. Res. 34: 431-446.

Brandner, T.A., R.O. Peterson and K.L. Risenhoover. 1990. Balsam fir on Isle Royale: effects of moose herbivory and population density. Ecology 71: 155-164.

Brandt, J.P. 2009. The extent of the North American boreal zone. Environ. Rev. 17: 101-161.

Brandt, J.P., H.F. Cerezke, K.I. Mallett, W.J.A. Volney and J.D. Weber. 2003. Factors affecting trembling aspen (Populus tremuloides Michx.) health in the boreal forest of Alberta, Saskatchewan, and Manitoba, Canada. For. Ecol. Manage. 178: 287-300.

Brassard, B.W. and H.Y.H. Chen. 2006. Stand structural dynamics of North American boreal forests. Crit. Rev. Plant Sci. 25: 115-137.

Brassard, B.W., H.Y.H. Chen, Y. Bergeron and D. Paré. 2011. Differences in fine root productivity between mixed- and single-species stands. Functional Ecology 25: 238-246.

Brassard, B.W., H.Y.H. Chen, J.R. Wang and P.N. Duinker. 2008. Effects of time since stand-replacing fire and overstory composition on live-tree structural diversity in the boreal forest of central Canada. Can. J. For. Res. 38: 52-62.

Burton, P.J., C. Messier, W.L. Adamowicz and T. Kuuluvainen. 2006. Sustainable management of Canada's boreal forests: Progress and prospects. Écoscience 13: 234-248.

Campbell, E.M., D.A. MacLean and Y. Bergeron 2008. The severity of budworm-caused growth reductions in balsam fir/spruce stands varies with the hardwood content of surrounding forest landscapes. For. Sci. 54: 195-205.

[CCFM] Canadian Council of Forest Ministers. 2008. A vision for Canada's forests: 2008 and beyond. Canadian Forest Service, Ottawa.

Candau, J.-N.l., R.A. Fleming and A. Hopkin. 1998. Spatiotemporal patterns of large-scale defoliation caused by the spruce budworm in Ontario since 1941. Can. J. For. Res. 28: 1733-1741.

Caners, R. and N.C. Kenkel. 2003. Forest stand structure and dynamics at Riding Mountain National Park, Manitoba, Canada. Comm. Ecol. 4: 185-204.

Carleton, T.J. and P.F. Maycock. 1978. Dynamics of the boreal forest south of James Bay. Can. J. Bot. 56: 1157-1173.

Cappuccino, N., D. Lavertu, Y. Bergeron and J. Régnière. 1998. Spruce budworm impact, abundance and parasitism rate in a patchy landscape. Oecologia 114: 236-242.

Cater, T.C. and F.S. Chapin III. 2000. Differential effects of competition or microenvironment on boreal tree seedling establishment after fire. Ecology 81: 1086-1099.

Cattelino, P.J., I.R. Noble, R.O. Slatyer and S.R. Kessell. 1979. Predicting the multiple pathways of plant succession. Environmental Management 3: 41-50. 
Cavard, X., S.E. Macdonald, Y. Bergeron and H.Y.H. Chen. 2011. Are mixedwoods important for biodiversity conservation: evidence for understory plants, songbirds, soil fauna and ectomycorrhizae in boreal and northern temperate forests. Environ. Rev. 19: 142-161.

Charron, I. and D.F. Greene. 2002. Post-wildfire seedbeds and tree establishment in the southern mixedwood boreal forest. Can. J. For. Res. 32: 1607-1615.

Chen, H.Y.H., K. Klinka, A.-H. Mathey, X. Wang, P. Varga and C. Chourmouzis. 2003. Are mixed-species stands more productive than single-species stands: an empirical test of three forest types in British Columbia and Alberta. Can. J. For. Res. 33: 1227-1237.

Chen, H.Y.H. and R.V. Popadiouk. 2002. Dynamics of North American boreal mixedwoods. Environ. Rev. 10: 137-166.

Chen, H.Y.H. and A.R. Taylor. 2012. A test of ecological succession hypotheses using 55-year time-series data for 361 boreal forest stands. Global Ecol. Biogeogr. 21: 441-454.

Chen, H.Y.H., S. Vasiliauskas, G.J. Kayahara and T. Ilisson. 2009. Wildfire promotes broadleaves and species mixture in boreal forest. For. Ecol. Manage. 257: 343-350.

Cogbill, C.V. 1985. Dynamics of the boreal forests of the Laurentian Highlands, Canada. Can. J. For. Res. 15: 252-261.

Colford-Gilks, A.K., D.A. MacLean, J.A. Kershaw and M. Bland. 2012. Growth and mortality of balsam fir- and spruce-tolerant hardwood stand as influenced by stand characteristics and spruce budworm defoliation. For. Ecol. Manage. 280: 82-92.

Cooke, B.J. and F. Lorenzetti. 2006. The dynamics of forest tent caterpillar outbreaks in Québec, Canada. For. Ecol. Manage. 226: 110-121.

Cooke, B.J. and J. Roland. 2007. Trembling aspen responses to drought and defoliation by forest tent caterpillar and reconstruction of recent outbreaks in Ontario. Can. J. For. Res. 37: 1586-1598.

Cumming, S.G. 2001. Forest type and wildfire in the Alberta boreal mixedwood: What do fires burn? Ecol. Appl. 11: 97-110.

Cumming, S.G., F.K.A. Schmiegelow and P.J. Burton. 2000. Gap dynamics in boreal aspen stands: is the forest older than we think? Ecol. Appl. 10: 744-759.

De Grandpré, L. and Y. Bergeron. 1997. Diversity and stability of understorey communities following disturbance in the southern boreal forest. J. Ecol. 85: 777-784.

De Grandpré, L., J. Morissette and S. Gauthier. 2000. Long-term post-fire changes in the northeastern boreal forest of Quebec. J. Veg. Sci. 11: 791-800.

DeLong, H.B., V.J. Lieffers and P.V. Blenis. 1997. Microsite effects on first-year establishment and overwinter survival of white spruce in aspen-dominated boreal mixedwoods. Can. J. For. Res. 27: 1452-1457. Dix, R.L. and J.M.A. Swan. 1971. The roles of disturbance and succession in upland forest of Candle Lake, Saskatchewan. Can. J. Bot. 49: 657-676.

Donkor, N.T. and J.M. Fryxell. 1999. Impact of beaver foraging on structure of lowland boreal forests of Algonquin Provincial Park, Ontario. For. Ecol. Manage. 118: 83-92.

Drobyshev, I., S. Gewehr, F. Berninger and Y. Bergeron. 2012. Species specific growth responses of black spruce and trembling aspen may enhance resilience of boreal forest to climate change. J. Ecol. 101: 231-242.

Duchesne, L. and R. Ouimet. 2009. Relationships between structure, composition, and dynamics of the pristine northern boreal forest and air temperature, precipitation, and soil texture in Quebec (Canada). Intl. J. For. Res. 2009: 1-13.

Fauria, M.M. and E.A. Johnson. 2008. Climate and wildfires in the North American boreal forest. Phil. Trans. Royal Soc. London. Series B, Biol. Sci. 363: 2317-2329.

Frelich, L.E. and P.B. Reich. 1995. Spatial patterns and succession in a Minnesota southern-boreal forest. Ecol. Monogr. 65: 325-346.

Frey, B.R, V.J. Lieffers, E.H. Hogg and S.M. Landhäusser. 2004. Predicting landscape patterns of aspen dieback: mechanisms and knowledge gaps. Can. J. For. Res. 34: 1379-1390.
Frey, B.R., V.J. Lieffers, S.M. Landhausser, P.G. Comeau and K.J. Greenway. 2003. An analysis of sucker regeneration of trembling aspen. Can. J. For. Res. 33: 1169-1179.

Fulton, R.J. (ed.). 1989. Quaternary geology of Canada and Greenland. Geological Survey of Canada, Geology of Canada, No. 1.

Galipeau, C., D. Kneeshaw and Y. Bergeron. 1997. White spruce and balsam fir colonization of a site in the southeastern boreal forest as observed 68 years after fire. Can. J. For. Res. 27: 139-147.

Gärtner, S.M., V.J. Lieffers and S.E. Macdonald 2011. Ecology and management of natural regeneration of white spruce in the boreal forest. Environ. Rev. 19: 461-478.

Gendreau-Berthiaume, B., D.D. Kneeshaw and B.D. Harvey. 2012. Is partial harvesting comparable to natural disturbances that partially remove the canopy in boreal mixedwoods? Forestry 85: 551-565.

Ghent, A.W. 1958. Mortality of overstory trembling aspen in relation to outbreaks of the forest tent caterpillar and the spruce budworm. Ecology 39: 222-232.

Greene, D.F., S.E. Macdonald, S. Cumming and L. Swift. 2005. Seedbed variation from the interior through the edge of a large wildfire in Alberta. Can. J. For. Res. 35: 1640-1647.

Greene, D.F. et al. 2007. The reduction of organic-layer depth by wildfire in the North American boreal forest and its effect on tree recruitment by seed. Can. J. For. Res. 37: 1012-1023.

Greene, D.F., J. Noel, Y. Bergeron, M. Rousseau and S. Gauthier. 2004. Recruitment of Picea mariana, Pinus banksiana, and Populus tremuloides across a burn severity gradient following wildfire in the southern boreal forest of Quebec. Can. J. For. Res. 34: 1845-1857.

Greene, D.F., J.C. Zasada, L. Sirois, D. Kneeshaw, H. Morin, I. Charron and M.J. Simard. 1999. A review of the regeneration dynamics of North American boreal forest tree species. Can. J. For. Res. 29: 824-839. Gutsell, S.L. and E.A. Johnson. 2002. Accurately ageing trees and examining their height-growth rates: implications for interpreting forest dynamics. J. Ecol. 90: 153-166.

Hare, F.K. and M.K. Thomas. 1979. Climate Canada. J. Wiley, Toronto.

Harvey, B., Y. Bergeron, S. Gauthier and A. Leduc. 2002. Standlandscape integration in natural disturbance-based management of the southern boreal forest. For. Ecol. Manage. 155: 371-388.

Hirsch, K., V. Kafka, C. Tymstra, R. McAlpine, B. Hawkes, H. Stegehuis, S. Quintilio, S. Gauthier and K. Peck. 2001. Fire-smart forest management: A pragmatic approach to sustainable forest management in fire-dominated ecosystems. For. Chron. 77: 357-363.

Hobson, K.A. and E. Bayne. 2000. Breeding bird communities in boreal forest of western Canada: consequences of "unmixing" the mixedwoods. Condor 102: 759-769.

Hogg, E.H., J.P. Brandt and B. Kochtubajda. 2002. Growth and dieback of aspen forests in northwestern Alberta, Canada, in relation to climate and insects. Can. J. For. Res. 32: 823-832.

Hogg, E.H., J.P. Brandt and M. Michaelian. 2008. Impacts of a regional drought on the productivity, dieback, and biomass of western Canadian aspen forests. Can. J. For. Res. 38: 1373-1384.

Hogg, E.H. and A.G. Schwarz. 1999. Tree-ring analysis of declining aspen stands in west-central Saskatchewan. Can. For. Serv. North. For. Cent. Inf. Rep. NOR-X-359.

Ilisson, T. and H.Y.H. Chen. 2009a. The direct regeneration hypothesis in northern forests. J. Veg. Sci. 20: 735-744.

Ilisson, T. and H.Y.H. Chen. 2009b. Response of six boreal tree species to stand replacing fire and clearcutting. Ecosystems 12: 820-829.

Jackson, S., F. Pinto, J.R. Malcolm and E.R. Wilson. 2000. A comparison of pre-European settlement (1857) and current (1981-1995) forest composition in central Ontario. Can. J. For. Res. 30: 605-612.

Johnston, C.A. and R.J. Naiman. 1990. Browse selection by beaver: effects on riparian forest composition. Can. J. For. Res. 20: 1036-1043. Johnson, E.A. 1992. Fire and vegetation dynamics: studies from the North American boreal forest. Cambridge Univ. Press, Cambridge.

Johnstone, J. and F.S. Chapin III. 2006a. Effects of soil burn severity on post-fire tree recruitment in boreal forest. Ecosystems 9: 14-31. 
Johnstone, J. and F.S. Chapin III. 2006b. Fire interval effects on successional trajectory in boreal forests of Northwest Canada. Ecosystems 9: 268-277.

Johnstone, J.F., F.S. Chapin III, J. Foote, S. Kemmett, K. Price and L. Viereck. 2004. Decadal observations of tree regeneration following fire in boreal forests. Can. J. For. Res. 34: 267-273.

Johnstone, J.F., T.N. Hollingsworth, F.S. Chapin III and M.C. Mack. 2010. Changes in fire regime break the legacy lock on successional trajectories in Alaskan boreal forest. Global Change Biol. 16: 1281-1295. Kabzems, R. and O. Garcia. 2004. Structure and dynamics of trembling aspen - white spruce mixed stands near Fort Nelson, B.C. Can. J. For. Res. 34: 384-395.

Kenkel, N.C., D.J. Walker, P.R. Watson, R.T. Caners and R.A. Lastra. 1997. Vegetation dynamics in boreal forest ecosystems. Coenoses 12 : 97-108.

Kneeshaw, D.D. and Y. Bergeron. 1996. Ecological factors affecting the abundance of advance regeneration in Quebec's southwestern boreal forest. Can. J. For. Res. 26: 888-898.

Kneeshaw, D.D. and Y. Bergeron. 1998. Canopy gap characteristics and tree replacement in the southeastern boreal forest. Ecology 79: 783-794.

Kneeshaw D., Y. Bergeron and T. Kuuluvainen. 2011. Forest ecosystem structure and disturbance dynamics across the circumboreal forest. In The SAGE Handbook of Biogeography. pp. 263-280. SAGE. Thousand Oaks, CA.

Kneeshaw, D. and S. Gauthier. 2003. Old growth in the boreal forest: a dynamic perspective at the stand and landscape level. Environ. Rev. 11 (Suppl. 1): S99-S114.

Kruger, E.L. and P.B. Reich. 1997. Responses of hardwood regeneration to fire in mesic forest openings. I. Post-fire community dynamics. Can. J. For. Res. 27: 1822-1831.

Kurkowski, T.A., D.H. Mann, T.S. Rupp and D.L. Verbyla. 2008. Relative importance of different successional pathways in an Alaskan boreal forest. Can. J. For. Res. 38: 1911-1923.

Kurmis, V. and E. Sucoff. 1989. Population density and height distribution of Corylus cornuta in undisturbed forests of Minnesota: 1965-1984. Can. J. Bot. 67: 2409-2413.

Landhäusser, S.M., D. Deshaies, and V.J. Lieffers. 2010. Disturbance facilitates rapid range expansion of aspen into higher elevations of the Rocky Mountains under a warming climate. J. Biogeogr. 37: 68-76.

Landhäusser, S.M. and V.J. Lieffers. 1998. Growth of Populus tremuloides in association with Calamagrostis canadensis. Can. J. For. Res. 28: 396-401.

Landhäusser, S.M., T.L. Mulak and V.J. Lieffers. 2007. The effect of roots and litter of Calamagrostis canadensis on root sucker regeneration of Populus tremuloides. Forestry 80: 481-488.

Larsen, J.A. 1980. The boreal ecosystem. Academic Press, New York. Lenihan, J.M. 1993. Ecological response surfaces for North American boreal tree species and their use in forest classification. J. Veg. Sci. 4: $667-680$.

Levac, J. 2012. Long-term stand dynamics of the boreal mixed-wood forests of west-central Manitoba. M.Sc. thesis, University of Manitoba. Available at http://hdl.handle.net/1993/5234

Lieffers, V.J., G.W. Armstrong, K.J. Stadt and E.H. Marenholtz. 2008. Forest regeneration standards: Are they limiting management options for Alberta's boreal mixedwoods? For. Chron. 84: 76-82.

Lieffers, V.J., R.B. Macmillan, D. MacPherson, K. Branter and J.D. Stewart. 1996a. Semi-natural and intensive silvicultural systems for the boreal mixedwood forest. For. Chron. 72: 286-292.

Lieffers, V.J., K.J. Stadt and S. Navratil. 1996b. Age structure and growth of understory white spruce under aspen. Can. J. For. Res. 26: 1002-1007.

Macdonald, G.B. 1995. The case for boreal mixedwood management: an Ontario perspective. For. Chron. 71: 725-734.

MacIsaac, D.A., P.G. Comeau and S.E. Macdonald. 2006. Gap dynamics of regeneration following harvest of aspen stands. Can. J. For. Res. 36: 1818-1833.
MacKinnon, W.E. and D.A. MacLean. 2003. The influence of forest and stand conditions on spruce budworm defoliation in New Brunswick, Canada. For. Sci. 49: 657-667.

MacKinnon, W.E. and D.A. MacLean. 2004. Effects of surrounding forest and site conditions on growth reduction of balsam fir and spruce caused by spruce budworm defoliation. Can. J. For. Res. 34: 2351-2362. MacLean, D.A. and W.E. MacKinnon. 1997. Effects of stand and site characteristics on susceptibility and vulnerability of balsam fir and spruce to spruce budworm in New Brunswick. Can. J. For. Res. 27: 1859-1871.

Man, R. and V.J. Lieffers. 1999. Are mixtures of aspen and white spruce more productive than single species stands? For. Chron. 75: 505-513.

Man, R. and J.A. Rice. 2010. Response of aspen stands to forest tent caterpillar defoliation and subsequent overstory mortality in northeastern Ontario, Canada. Forest Ecol. Manage. 260: 1853-1860.

McCarthy, J. 2001. Gap dynamics of forest trees: a review with particular attention to boreal forests. Environ. Rev. 9: 1-59.

McCullough, D.G., R.A. Werner and D. Neumann. 1998. Fire and insects in northern and boreal forest ecosystems on North America. Ann. Rev. Entomol. 43: 107-127.

McIntire, E.J.B., R. Duchesneau and J.P. Kimmins. 2005. Seed and bud legacies interact with varying fire regimes to drive long-term dynamics of boreal forest communities. Can. J. For. Res. 35: 2765-2773.

Meng, S.X., S. Huang, V.J. Lieffers and Y. Yang. 2008. Modeling the change in aspen species composition in boreal mixedwoods. Forestry 81: 575-586.

Messier, C., S. Parent and Y. Bergeron. 1998. Effects of overstory and understory vegetation on the understory light environment in mixed boreal forests. J. Veg. Sci. 9: 511-520.

Messier, C., K.J. Puettmann and D.K. Coates. 2013. Managing forests as complex adaptive systems - Building resilience to the challenge of global change. Routledge, New York.

Morin, H. 1994. Dynamics of balsam fir forests in relation to spruce budworm outbreaks in the boreal zone, Québec. Can. J. For. Res. 24: 730-741.

Morin, H., D. Laprise and Y. Bergeron. 1993. Chronology of spruce budworm outbreaks near Lake Duparquet, Abitibi region, Quebec. Can. J. For. Res. 23: 1497-1506.

Moss, E.H. 1953. Forest communities in northwestern Alberta. Can. J. Bot. 31: 212-252.

Moulinier, J., F. Lorenzetti and Y. Bergeron. 2011. Gap dynamics in aspen stands of the Clay Belt of northwestern Quebec following a forest tent caterpillar outbreak. Can. J. For. Res. 41: 1606-1617.

Mundell, T.L., S.M. Landhäusser and V.J. Lieffers. 2007. Effects of Corylus cornuta stem density on root suckering and rooting depth of Populus tremuloides. Can. J. Bot. 85: 1041-1045.

Nixon, A.E. and J. Roland. 2012. Generalist predation on forest tent caterpillar varies with forest stand composition: an experimental study across multiple life stages. Ecol. Ent. 37: 13-23.

Oliver, C.D. and B.C. Larson. 1996. Forest stand dynamics. J. Wiley, New York.

Park, A., D. Kneeshaw, Y. Bergeron and A. Leduc. 2005. Spatial relationship and tree species associations across a 236-year boreal mixedwood chronosequence. Can. J. For. Res. 35: 750-761.

Pastor, J., B. Dewey, R.J. Naiman, P.F. McInnes and Y. Cohen. 1993. Moose browsing and soil fertility in the boreal forests of Isle Royale National Park. Ecology 74: 467-480.

Pastor, J. and R.J. Naiman. 1992. Selective foraging and ecosystem processes in boreal forests. Am. Nat. 139: 690-705.

Peters, V.S. 2002. Keystone processes affect succession in boreal mixedwoods - the relationship between masting in white spruce and fire history. Ph.D. thesis. University of Alberta, Edmonton, AB.

Peters, V.S., S.E. Macdonald, and M.R.T. Dale. 2005. The masting phenomenon in relation to fire is key to white spruce regeneration. Ecology 86: 1744-1750. 
Peters, V.S., S.E. Macdonald and M.R.T. Dale. 2006. Patterns of initial versus delayed regeneration of white spruce in boreal mixedwood succession. Can. J. For. Res. 36: 1597-1609.

Peterson, C.J. 2004. Within-stand variation in windthrow in southern boreal forests of Minnesota: Is it predictable? Can. J. For. Res. 34: 365-375.

Pham, A.T., L. De Grandpré, S. Gauthier and Y. Bergeron. 2004. Gap dynamics and replacement patterns in gaps of the northeastern boreal forest of Quebec. Can. J. For. Res. 34: 353-364.

Pothier, D., F. Raulier and M. Riopel. 2004. Ageing and decline of trembling aspen stands in Quebec. Can. J. For. Res. 34: 1251-1258.

Pothier, D. and F. Savard. 1998. Actualisation des tables de production pour les principales espèces forestières du Québec: Ministère des Ressources naturelles.

Potvin, F., P. Beaupre and G. Laprise. 2003. The eradication of balsam fir stands by white-tailed deer on Anticosti Island, Quebec: a 150-year process. Écoscience 10: 487-495.

Puettmann, K.J., K.D. Coates and C. Messier. 2009. A critique of silviculture: Managing for complexity. Island Press, Washington, DC.

Purdy, B.G., S.E. Macdonald and M.R.T. Dale. 2002. The regeneration niche of white spruce following fire in the mixedwood boreal forest. Silva Fennica 36: 289-306.

Reinikainen, M., A.W. D’Amato and S. Fraver. 2012. Repeated insect outbreaks promote multi-cohort aspen mixedwood forests in northern Minnesota, USA. For. Ecol. Manage. 266: 148-159.

Rich, R.L., L.E. Frelich and P.B. Reich. 2007. Wind-throw mortality in the southern boreal forest: effects of species, diameter and stand age. J. Ecol. 95: 1261-1273.

Römer, A.H., D.D. Kneeshaw and Y. Bergeron. 2007. Small gap dynamics in the southern boreal forest of eastern Canada: Do canopy gaps influence stand development? J. Veg. Sci. 18: 815-826.

Rosell, F., O. Bozser, P. Collen and H. Parker. 2005. Ecological impact of beavers Castor fibre and Castor canadensis and their ability to modify ecosystems. Mammal Reviews 35: 248-276.

Rounds, R.C. 1979. Height and species as factors determining browsing of shrubs by wapiti. J. Appl. Ecol. 16: 227-241.

Rowe, J.S. 1961. Critique of some vegetational concepts as applied to forests of northwestern Alberta. Can. J. Bot. 39: 1007-1017.

Rowe J.S. and G.W. Scotter. 1973. Fire in the boreal forest. Quat. Res. 3: 444-464

Ruel, J.-C. 1995. Understanding windthrow: silvicultural implications. For. Chron. 71: 434-445.

Schier, G.A. 1973. Origin and development of aspen root suckers Can. J. For. Res. 3: 45-53.

Senecal, D., D. Kneeshaw and C. Messier. 2004. Temporal, spatial, and structural patterns of adult trembling aspen and white spruce mortality in Quebec's boreal forest. Can. J. For. Res. 34: 396-404.

Shorohova, E., T. Kuuluvainen, A. Kangur and K. Jogiste. 2009. Natural stand structures, disturbance regimes and successional dynamics in the Eurasian boreal forests: a review with special reference to Russian studies. Ann. For. Sci. 66: 201-201.

Simard, M.J., Y. Bergeron and L. Sirois. 1998. Conifer seedling recruitment in a southeastern Canadian boreal forest: the importance of substrate. J. Veg. Sci. 9: 575-582
Simard, M.J., Y. Bergeron and L. Sirois. 2003. Substrate and litterfall effects on conifer seedling survivorship in southern boreal stands of Canada. Can. J. For. Res. 33: 672-681.

Stewart, J.D., E.H. Hogg, P.A. Hurdle, K.J. Stadt, P. Tollestrup and V.J. Lieffers. 1998. Dispersal of white spruce seed in mature aspen stands. Can. J. Bot. 76: 181-188.

Su, Q., D.A. MacLean and T.D. Needham. 1996. The influence of hardwood content on balsam fir defoliation by spruce budworm. Can. J. For. Res. 26: 1620-1628.

Sutton, A. and J.C. Tardif. 2007. Dendrochronological reconstruction of forest tent caterpillar outbreaks in time and space, western Manitoba, Canada. Can. J. For. Res. 37: 1643-1657.

Talbot, S.S. and W.J. Meades. 2011. Circumboreal Vegetation Map (CBVM): Mapping the Green Halo. Concept Paper. CAFF Strategy Series Report No. 3. CAFF Flora Group (CFG), CAFF International Secretariat, Akureyri, Iceland. ISBN 978-9935-431-05-9. Available at www.caff.is/flora-cfg/circumboreal-vegetation-map

Taylor, A.R. and H.Y.H. Chen. 2011. Multiple successional pathways of boreal forest stands in central Canada. Ecography 34: 208-219.

Taylor, A.R., H.Y.H. Chen and L. van Damme. 2009. A review of forest succession models and their suitability to forest management planning. For. Sci. 55: 23-36.

Taylor, S.L. and D.A. MacLean. 2005. Rate and causes of decline of mature and overmature balsam fir and spruce stands in New Brunswick, Canada. Can. J. For. Res. 35: 2479-2490.

Taylor, S.L. and D.A. MacLean. 2007. Legacy of insect defoliators: Increased wind-related mortality two decades after a spruce budworm outbreak. For. Sci. 55: 256-267.

Terrier, A., M.P. Girardin, C. Périé, P. Legendre and Y. Bergeron. 2013. Potential changes in forest composition could reduce impacts of climate change on boreal wildfires. Ecol. Appl. 23: 21-35.

Trottier, G.C. 1981. Beaked hazelnut - a key browse species for moose in the boreal forest region of western Canada. Alces 17: 257-281.

Waldron, R.M. 1959. Hazel foliage treatments to reduce suppression of white spruce reproduction. Forest Research Division, Technical Note No. 75. Department of Northern Affairs and National Resources, Ottawa.

Youngblood, A. 1995. Development patterns in young conifer and hardwood forests of interior Alaska. J. Veg. Sci. 6: 229-236.

Zasada, J.C., T.L. Sharik and N. Markku. 1992. The reproductive process in boreal forest trees. In H.H. Shugart, R. Leemans and G.B. Bonan (eds.). A systems analysis of the global boreal forest. pp. 85-125. Cambridge Univ. Press, New York.

Zhang, Y., H.Y.H. Chen, and P.B. Reich. 2012. Forest productivity increases with evenness, species richness and trait variation: a global meta-analysis. J. Ecol. 100: 742-749.

Zhong, J., and B. van der Kamp. 1999. Pathology of conifer seed and timing of germination in high-elevation subalpine fir and Engelmann spruce forest of the southern interior of British Columbia. Can. J. For. Res 29: 187-193

Zoladeski, C.A. and P.F. Maycock. 1990. Dynamics of the boreal forest in northwestern Ontario. Am. Midl. Nat. 124: 289-300. 